\title{
Initial experience with bioresorbable vascular scaffolds for percutaneous revascularisation in patients with acute coronary syndrome
}

\author{
Alberto Cordero, Ramón López-Palop, Pilar Carrillo, Araceli Frutos, Clara Gunturiz, Maria García-Carrilero, \\ Vicente Bertomeu-Martinez
}

Department of Cardiology, Hospital Universitario de San Juan, Alicante 03540, Spain.

Correspondence to: Dr. Alberto Cordero, Department of Cardiology, Hospital Universitario de San Juan, Alicante 03540, Spain. E-mail: acorderofort@gmail.com

How to cite this article: Cordero A, López-Palop R, Carrillo P, Frutos A, Gunturiz C, García-Carrilero M, Bertomeu-Martinez V. Initial experience with bioresorbable vascular scaffolds for percutaneous revascularisation in patients with acute coronary syndrome. Vessel Plus 2017;1:68-76.

Article history:

Received: 21-01-2017

Accepted: 22-03-2017

Published: 27-06-2017

Key words:

Bioresorbable vascular stents,

stents,

acute coronary syndrome,

revascularisation,

prognosis

\begin{abstract}
Aim: Bioresorbable vascular scaffolds (BVS) have recently been introduced to minimise the long-term complications of metallic stents in acute coronary syndrome (ACS), but their benefits have not been well analysed. Methods: The authors studied all ACS patients treated with any kind of stent at a single centre between March 2013 (when the first BVS was implanted) and June 2016. Results: The study included 951 subjects, mean age $67.9 \pm 13.3$ years, mean Global Registry of Acute Coronary Events (GRACE) score 148.5 $\pm 44.8,75.2 \%$ men and $38.2 \%$ with an ST-segment elevation myocardial infarction. The mean number of stents implanted was $1.3 \pm 1.0$ and 54 subjects $(5.7 \%)$ received at least 1 BVS. Drug-eluting stents were implanted in $57.3 \%$ subjects, followed by bare-metal stents $(19.0 \%)$. The subjects treated with BVS were younger and had lower GRACE scores compared to the rest. Inhospital mortality was $4.8 \%$ and no subject treated with BVS died before discharge. BVStreated patients received dual antiplatelet therapy or new antiplatelet agents more frequently. During a median follow-up of 13 months, all-cause mortality was $7.8 \%$, cardiovascular mortality was $6.1 \%$, and at least 1 major cardiovascular event occurred in $26.4 \%$ of the subjects. Stent type did not affect prognosis. Conclusion: Coronary revascularisation using BVS in selected ACS patients is safe and effective.
\end{abstract}

\section{INTRODUCTION}

Cardiovascular disease is the leading cause of mortality in the world, and coronary heart disease is the primary contributor to that cardiovascular mortality. ${ }^{[1]}$ Coronary heart disease is a progressive condition resulting from atherosclerosis that produces unstable coronary plaque, with episodes of erosion and intraluminal thrombosis that become manifest as an acute coronary syndrome (ACS), ${ }^{[2]}$ ventricular fibrillation, asystole, and sudden death. Percutaneous coronary interventions are the cornerstone of ACS treatment, and coronary stents are utilised in almost all of these. ${ }^{[3-5]}$ Bare-metal stents (BMS) were the first devices developed to improve the results of balloon angioplasty by the resolving post-balloon dissections,

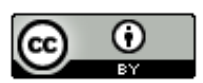

This is an open access article licensed under the terms of Creative Commons Attribution 4.0 International License (https://creativecommons.org/licenses/by/4.0/), which permits unrestricted use, distribution, and reproduction in any medium, as long as the original author is credited and the new creations are licensed under the identical terms.

For reprints contact: service@oaepublish.com

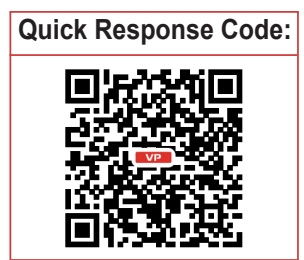


and preventing coronary wall recoil and constrictive remodelling. ${ }^{[6]}$ Percutaneous coronary intervention $(\mathrm{PCl})$ with stents was progressively adopted as the standard of care for interdiction of ACS, myocardial ischemia and infarction..$^{[7]}$ However, as this strategy was being adopted it became clear that stent restenosis was a frequent and potentially fatal complication in patients treated with BMS. ${ }^{[6]}$ Drug-eluting stents (DES) largely overcame the restenosis problem with BMS but they were also linked to many long-term complications such as late stent-thrombosis, neo-atherosclerosis, side-branch jailing and/or preclusion of future surgical revascularisation at the same lesion. ${ }^{[8]}$

Bioresorbable vascular scaffolds (BVS) are newly adopted device for coronary stenting and were designed to minimise the long-term complications of stents ${ }^{[6]}$ by providing an on-permanent scaffold. ${ }^{\left[{ }^{[0]}\right.}$ The first BVS was designed and tested in humans at the end of last century and now shows promising results in terms of feasibility and complete reabsorption. ${ }^{[10]}$ Several randomised clinical trials and meta-analyses have outlined the usefulness of BVS for coronary revascularisation, ${ }^{[11-13]}$ although the clinical benefit for ACS patients has not been well analysed. ${ }^{[14,15]}$ The objective of our study was to report the safety and utility of BVS compared to other stents in a cohort of ACS patients.

\section{METHODS}

\section{Study design}

In 2009, we initiated an ongoing prospective registry of all patients admitted for ACS in our institution. Several results have already been published. ${ }^{[5,16]}$ For this study, we included all patients admitted with the diagnosis of ACS between January 2013 and March 2016, resulting in a cohort of 951 consecutive subjects. The patients were classified according to the stent type that was used and the cohort was divided in 4 groups: no stent, BMS, DES, or BVS. The interventional cardiologist made the treatment decisions and stent selection after considering the clinical situation. The DES implanted during the study period were all second- and thirdgeneration devices. Intravascular ultrasound and optical coherence tomography were performed in most cases where a BVS was implanted but the final decisions were made according to the treating physicians' clinical judgements.

ACS was defined by the presence of typical clinical symptoms of unstable angina or impending myocardial infarction. ACS was classified as ST-elevation myocardial infarction (STEMI) and non-STEMI according to the electrocardiographic findings. The mortality risk was assessed by the Global Registry of Acute Coronary Events (GRACE) score; according to individual scores patients with categorised in low risk < 108), intermediate risk (109-130) and high-risk (> 140). ${ }^{[3]}$ All patients with STEMI received primary $\mathrm{PCl}$ and patients with non-STEMI were referred for $\mathrm{PCl}$, if appropriate as determined by a comprehensive medical evaluation. According to previous reports, incomplete coronary revascularisation was defined as when at least one of the main coronary arteries, or a secondary branch $>1.5 \mathrm{~mm}$, with significant lesions $(>70 \%)$, was treated but not fully revascularised. ${ }^{[17,18]}$

Risk factors, clinical antecedents, treatments, complementary tests, and main diagnosis at discharge were tabulated for all subjects by trained medical staff. ${ }^{[5]}$ For the diagnosis of previous coronary artery disease, subjects needed to have a clinical diagnosis of myocardial infarction, stable or unstable angina or known prior coronary revascularisation. Previous heart failure was determined based upon their prior clinical diagnosis of heart failure. Glomerular filtration rate was estimated from serum creatinine values with the Modification of Diet in Renal Disease Study equation. Overall estimation of comorbidities was assessed by the Charlson Index, adapted for patients with coronary heart disease; ${ }^{[19]}$ patients with a Charlson score $\geq 4$ were considered as having high-comorbidity risks. Following current recommendations, optimal medical treatment was codified when patients received prescriptions for four medical treatments: an antiplatelet agent, a statin, a beta-adrenergic blocker, and an angiotensinconverter enzyme inhibitor or angiotensin-receptor blocker. ${ }^{[20,21]}$ Statin treatment was classified as low intensity, moderate intensity, or high intensity based on the current guidelines. ${ }^{[22,23]}$ Ticagrelor and prasugrel were analysed together as a group of new antiplatelet agents in place of clopidogrel.

The post-discharge follow-up of all subjects followed a well-established protocol. The end-points analysed were cardiovascular and all-cause mortality as well as time to first major cardiovascular event (MACE) (ACS, heart failure hospitalisation, fatal or non-fatal stroke, or major bleeding). Two staff members reviewed clinical records, and (in absence of hospital contact), the electronic medical history was consulted for outpatient follow-up care. All physicians in the geographic area use a unified electronic medical record (EMR) that documents every contact with the health care system, for either medical or nursing visits. If electronic medical reports were lacking, one nurse who had been trained to acquire the needed data by telephone was directed to call the subject and assess all endpoints through a follow-up conversation. All emergency calls, visits 
Table 1: Clinical features of the cohort according to the stent type

\begin{tabular}{|c|c|c|c|c|c|}
\hline Characteristics & No stent & BMS & DES & BVS & $\boldsymbol{P}$ \\
\hline Number & $171(18.0 \%)$ & $181(19.9 \%)$ & $545(57.3 \%)$ & $54(5.7 \%)$ & \\
\hline Age (years), mean \pm SD & $71.4 \pm 13.0$ & $72.4 \pm 13.8$ & $66.5 \pm 12.3$ & $56.4 \pm 12.7$ & $<0.01^{\#}$ \\
\hline Age $>75$ years & $41.5 \%$ & $50.3 \%$ & $26.1 \%$ & $5.6 \%$ & $<0.01$ \\
\hline Males & $63.2 \%$ & $74.6 \%$ & $78.0 \%$ & $87.0 \%$ & $<0.01$ \\
\hline Diabetes & $32.7 \%$ & $35.9 \%$ & $29.7 \%$ & $31.5 \%$ & 0.47 \\
\hline Hypertension & $70.8 \%$ & $69.1 \%$ & $59.8 \%$ & $38.9 \%$ & $<0.01$ \\
\hline Current smokes & $19.9 \%$ & $24.9 \%$ & $36.5 \%$ & $50.0 \%$ & $<0.01$ \\
\hline Dyslipidemia & $49.7 \%$ & $50.3 \%$ & $47.0 \%$ & $42.6 \%$ & 0.70 \\
\hline Previous HF & $7.6 \%$ & $2.8 \%$ & $1.8 \%$ & $0.0 \%$ & $<0.01$ \\
\hline Previous CHD & $25.1 \%$ & $21.5 \%$ & $22.4 \%$ & $5.6 \%$ & 0.02 \\
\hline Previous $\mathrm{PCl}$ & $14.7 \%$ & $10.1 \%$ & $16.7 \%$ & $3.7 \%$ & 0.02 \\
\hline Previous CABG & $7.1 \%$ & $3.6 \%$ & $4.0 \%$ & $0.0 \%$ & 0.13 \\
\hline Peripheral arterial disease & $7.6 \%$ & $7.2 \%$ & $4.6 \%$ & $5.6 \%$ & 0.37 \\
\hline Atrial fibrillation & $15.8 \%$ & $14.4 \%$ & $4.4 \%$ & $0.0 \%$ & $<0.01$ \\
\hline Previous stroke & $10.5 \%$ & $13.3 \%$ & $5.1 \%$ & $3.7 \%$ & $<0.01$ \\
\hline COPD & $9.4 \%$ & $12.7 \%$ & $10.3 \%$ & $9.3 \%$ & 0.73 \\
\hline STEMI & $11.1 \%$ & $46.4 \%$ & $43.5 \%$ & $42.6 \%$ & $<0.01$ \\
\hline GFR $\left(\mathrm{mL} / \mathrm{min} / 1.72 \mathrm{~m}^{2}\right)$, mean $\pm \mathrm{SD}$ & $78.3 \pm 38.5$ & $70.7 \pm 29.6$ & $82.8 \pm 31.3$ & $82.9 \pm 22.9$ & $<0.01^{\#}$ \\
\hline $\mathrm{GFR}<60 \mathrm{~mL} / \mathrm{min} / 1.72 \mathrm{~m}^{2}$ & $26.3 \%$ & $40.7 \%$ & $16.7 \%$ & $15.4 \%$ & $<0.01$ \\
\hline GRACE score, mean \pm SD & $146.8 \pm 50.6$ & $162.6 \pm 46.0$ & $145.6 \pm 42.3$ & $124.8 \pm 29.7$ & $<0.01^{\#}$ \\
\hline GRACE $>140$ & $42.9 \%$ & $67.1 \%$ & $51.4 \%$ & $32.7 \%$ & $<0.01$ \\
\hline Charlson index, mean $\pm S D$ & $2.6 \pm 2.9$ & $2.7 \pm 2.4$ & $2.2 \pm 1.8$ & $2.1 \pm 2.1$ & $0.03^{*}$ \\
\hline Charlson index $\geq 4$ & $23.4 \%$ & $24.9 \%$ & $18.2 \%$ & $14.8 \%$ & 0.12 \\
\hline LVEF (\%), mean \pm SD & $54.6 \pm 13.0$ & $52.5 \pm 12.4$ & $53.3 \pm 12.5$ & $56.4 \pm 8.8$ & 0.07 \\
\hline
\end{tabular}

"For comparisons between BVS and the rest; *for comparisons between BVS or DES and the rest. BMS: bare metal stent; DES: drugeluting stents; BVS: bioresorvable vascular scaffold; HF: heart failure; CHD: coronary heart disease; PCI: percutaneous coronary intervention; CABG: coronary arterial bypass graft; COPD: chronic obstructive pulmonary disease; STEMI: ST-elevation myocardial infarction; GFR: glomerular filtration rate; GRACE: Global Registry of Acute Coronary Events; LVEF: left ventricle ejection fraction

to the emergency room of the hospital, or hospital readmissions also are registered in the single informatics application. Fatalities directly related to cardiac events, such as ACS, heart failure hospitalisation or sudden death were attributed to cardiovascular causes; noncardiovascular mortality was coded when another concurrent process was thought to be the main cause of the fatality, representing mainly infections, cancer deaths or accidents. The ethics committee of the hospital approved the protocol for the study and for obtaining informed consent from the subjects.

\section{Statistical analysis}

Data were processed with IBM SPSS 22.0 and STATA 14-0 statistical packages for Mac computers. Quantitative variables are presented as mean \pm standard deviation (SD) and differences were assessed by a Students $t$-test or Chi-squared tests. Qualitative variables are presented as percentages and differences were analysed by the analysis of variance (ANOVA) test. An analysis of interactions and collinearity between main clinical variables was performed and results were taken under consideration for further analysis. Statistical differences were accepted as significant if the $P$ value was $<0.05$.

Cox regression models performed survival analyses once the proportional risk tests were verified. The model was adjusted by all variables that obtained $P$ values $<0.1$ in the univariate analysis or could have plausible clinical implications; results are presented as the hazard ratio (HR) and 95\% confidence intervals (Cl). Stent type was analysed as a categorical variable in dummy models. The model's discriminative accuracy was assessed by the Harrell's C-statistic, and its calibration was verified by the Gronnesby and Borgan test. Analysis of recurrent cardiovascular events was performed by negative binomial regression, and results are presented as incidence rate ratio (IRR) and rates/100 patients/year. ${ }^{[24]}$

\section{RESULTS}

During the study period, a total of 951 patients were enrolled as subjects. They had a mean age of $67.9( \pm$ 13.4 ) years, $75.2 \%$ were male, $38.2 \%$ were diagnosed with STEMI, and their mean GRACE score was 148.5 $( \pm 44.8)$. The revascularisation strategies included DES (57.3\%) and BMS (19.0\%); 54 (5.7\%) received at least 1 BVS [Table 1]. In 171 subjects ( $18.0 \%)$, no stents were placed after the angiography and diagnostic studies were done. BVS-treated patients were the younger, and had the highest percentage of current smokers but the lowest prevalence of known heart failure, atrial fibrillation, or stroke. No differences were observed in 
Table 2: Procedure and coronary lesions characteristics

\begin{tabular}{|c|c|c|c|c|c|}
\hline Characteristics & No stent & BMS & DES & BVS & $P$ \\
\hline Radial approach & $93.0 \%$ & $96.4 \%$ & $98.1 \%$ & $100.0 \%$ & 0.01 \\
\hline No. of vessels with lesions, mean $\pm S D$ & $0.8 \pm 1.1$ & $1.6 \pm 0.8$ & $1.7 \pm 0.8$ & $2.1 \pm 0.8$ & $<0.01$ \\
\hline No. of stents/patient, mean \pm SD & $0.0 \pm 0.0$ & $1.4 \pm 0.6$ & $1.6 \pm 0.9$ & $2.8 \pm 1.5$ & $<0.01$ \\
\hline Complete revascularization & $49.0 \%$ & $71.4 \%$ & $76.3 \%$ & $85.2 \%$ & $<0.01$ \\
\hline Left main disease & $7.1 \%$ & $0.6 \%$ & $6.1 \%$ & $0.0 \%$ & $<0.01$ \\
\hline Coronary lesions & & & & & $<0.01$ \\
\hline 1 vessel disease & $13.1 \%$ & $59.9 \%$ & $47.4 \%$ & $24.1 \%$ & \\
\hline 2 vessel disease & $13.1 \%$ & $22.2 \%$ & $29.8 \%$ & $42.6 \%$ & \\
\hline 3 vessel disease & $5.7 \%$ & $16.8 \%$ & $16.5 \%$ & $33.3 \%$ & \\
\hline $\mathrm{LM}+1$ vessel disease & $1.6 \%$ & $0.0 \%$ & $0.6 \%$ & $0.0 \%$ & \\
\hline $\mathrm{LM}+2$ vessel disease & $0.8 \%$ & $0.0 \%$ & $2.3 \%$ & $0.0 \%$ & \\
\hline $\mathrm{LM}+3$ vessel disease & $6.6 \%$ & $0.6 \%$ & $3.2 \%$ & $0.0 \%$ & \\
\hline
\end{tabular}

BMS: bare metal stent; DES: drug-eluting stents; BVS: bioresorvable vascular scaffold; LM: left main

Table 3: Medical treatments recommended at discharge according to the stent received within hospital revascularization

\begin{tabular}{|c|c|c|c|c|c|}
\hline Characteristics & No stent & BMS & DES & BVS & $P$ \\
\hline Aspirin & $76.9 \%$ & $96.4 \%$ & $96.6 \%$ & $98.1 \%$ & 0.01 \\
\hline Clopidogrel & $25.6 \%$ & $64.3 \%$ & $43.5 \%$ & $29.6 \%$ & $<0.01$ \\
\hline Ticagrelor & $5.8 \%$ & $14.9 \%$ & $28.3 \%$ & $31.5 \%$ & $<0.01$ \\
\hline Prasugrel & $0.0 \%$ & $17.3 \%$ & $25.6 \%$ & $38.9 \%$ & $<0.01$ \\
\hline Any new antiplatelet & $5.8 \%$ & $32.1 \%$ & $53.9 \%$ & $70.4 \%$ & $<0.01$ \\
\hline DAPT & $18.6 \%$ & $92.9 \%$ & $94.5 \%$ & $98.1 \%$ & $<0.01$ \\
\hline Oral anticoagulants & $14.1 \%$ & $10.1 \%$ & $5.3 \%$ & $0.0 \%$ & $<0.01$ \\
\hline ARB/ACEI & $71.2 \%$ & $79.2 \%$ & $82.0 \%$ & $79.6 \%$ & 0.03 \\
\hline Beta blockers & $64.7 \%$ & $83.3 \%$ & $88.4 \%$ & $90.7 \%$ & $<0.01$ \\
\hline Diuretics & $37.2 \%$ & $26.8 \%$ & $19.5 \%$ & $11.1 \%$ & $<0.01$ \\
\hline Statins & $69.2 \%$ & $95.2 \%$ & $95.1 \%$ & $96.3 \%$ & $<0.01$ \\
\hline High dose statin & $32.1 \%$ & $70.8 \%$ & $73.6 \%$ & $83.3 \%$ & $<0.01$ \\
\hline Moderate dose statin & $29.5 \%$ & $16.7 \%$ & $16.9 \%$ & $13.0 \%$ & $<0.01$ \\
\hline Low dose statin & $7.7 \%$ & $6.5 \%$ & $1.7 \%$ & $0.0 \%$ & $<0.01$ \\
\hline Nitrates & $19.9 \%$ & $6.5 \%$ & $4.7 \%$ & $1.9 \%$ & $<0.01$ \\
\hline Fibrates & $1.9 \%$ & $3.0 \%$ & $1.9 \%$ & $1.9 \%$ & 0.87 \\
\hline Ezetimibe & $1.9 \%$ & $0.6 \%$ & $4.0 \%$ & $1.9 \%$ & 0.10 \\
\hline Optimal medical treatment & $33.3 \%$ & $63.7 \%$ & $70.4 \%$ & $66.7 \%$ & $<0.01$ \\
\hline
\end{tabular}

BMS: bare metal stent; DES: drug-eluting stents; BVS: bioresorvable vascular scaffold; DAPT: double antiplatelet treatment; ARB: angiotensin receptor blocker; ACEI: angiotensin-converter enzyme inhibitors

the prevalence of diabetes or dyslipidaemia according to the stent type received. BMS-treated patients had the highest prevalence of comorbidities, reflected by the highest mean Charlson index.

The details of the revascularisation outcomes are presented in Table 2. The radial artery approach was utilised in most cases and in all BVS-treated subjects. The mean number of coronary lesions was $1.6( \pm 0.9)$ which was significantly higher in BVS-treated subjects; the mean number of stents per subject was $1.3( \pm 1.0)$ and BVS-treated cases also had the highest rate. As a consequence, the rate of complete revascularisation was the highest in patients treated with BVS. No BVS implantations were attempted in the left main coronary artery.

In-hospital mortality was $4.8 \%$ (46 patients out of 951) and no patient treated with BVS died prior to discharge.
The highest in-hospital mortality rate was observed in patients who were not (or could not be) stented (8.8\%), followed by those treated with BMS $(7.2 \%)$ and DES (3.3\%). As shown in Table 3, BVS-treated patients received the highest rate of dual antiplatelet treatment and $70 \%$ received a new antiplatelet drug (prasugrel or ticagrelor). Generally, patients treated with DES or BVS received more intensive medical treatments.

Post-discharge follow-up was achieved in $95.0 \%$ of the cohort, with median time of 13 months (interquartile range 9.0 to 22.0 ). All-cause mortality was $7.8 \%$, and cardiovascular mortality was $6.1 \%$. Additionally, $26.4 \%$ subjects experienced at least one MACE. Kaplan-Meier curves are presented in Figure 1. All-cause mortality varied according to stent type: no stent (13.5\%), BMS (10.1\%), DES (5.7\%), and BVS (5.6\%); the differences were significant (log-rank test, $P<0.01)$. Cardiovascular mortality declined in the same order: no stent $(10.3 \%)$, 

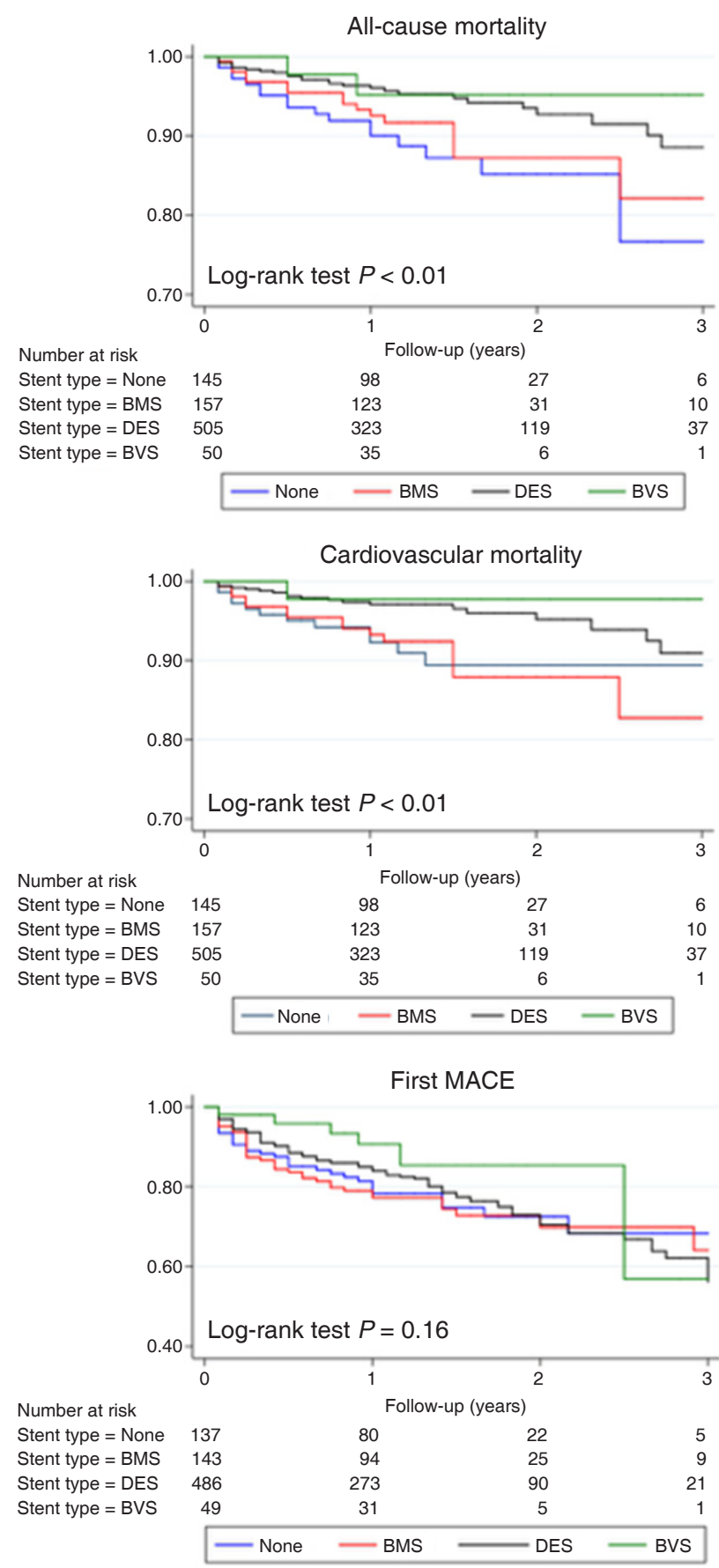

Figure 1: Kaplan-Myer curves presenting cardiovascular mortality, all-cause mortality and time to first major cardiovascular event (MACE) according to stent type. BMS: bare metal stent; DES: drugeluting stent; BVS: bioresorbable vascular scaffold

BMS (9.5\%), DES (4.0\%), and BVS (3.7\%) (log-rank test, $P<0.01)$. No differences were observed between DES and BVS in mortality rates. No differences were observed in the incidence of MACE according to stent type, although a tendency to lower incidence of time to first MACE was noted for BVS: no stent $(28.8 \%)$, BMS $(31.5 \%)$, DES $(25.5 \%)$, and BVS $(16.7 \%)(P=0.16)$. The highest rate of MACEs/year/100 patients was
MACEs/100 patients/year

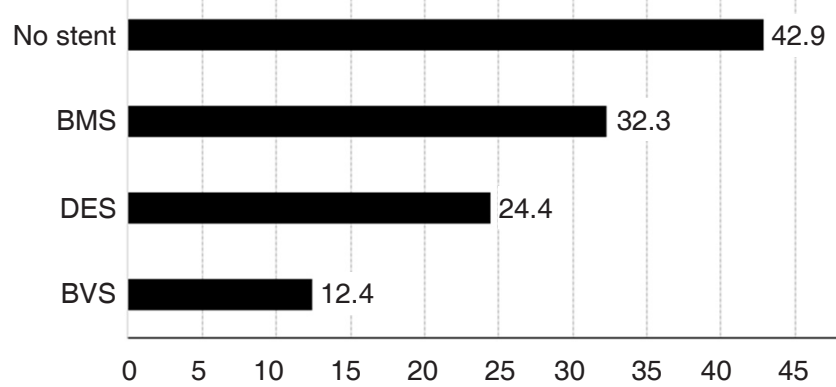

Figure 2: Major cardiovascular event (MACE) rates/100 patients/ year according to stent type. BMS: bare metal stent; DES: drugeluting stent; BVS: bioresorbable vascular scaffold

recorded in patients that received no stents, followed by BMS, DES, and BVS [Figure 2]. Multivariate analysis did not find any associations of mortality or cumulative MACEs with stent type [Table 4]. Diabetes, age $>75$ years and GRACE score $>140$ were associated with higher cardiovascular and all-cause mortality, whereas predictors of recurrent MACEs included age > 75 years, diabetes, and previous cardiovascular disease; revascularisation was negatively associated with recurrent events.

\section{DISCUSSION}

This single-centre experience with BVS supports their safety and effectiveness for revascularisation during ACS. BVS-treated patients had a lower risk profile despite the fact that they had more coronary lesions and were treated more aggressively, as they received a higher number of stents, more complete revascularisation, and more intensive antiplatelet and statin regimens.

Decision-making for stent use is influenced by many factors related to patient characteristics, coronary lesions, and other risks. DES were introduced to better control the rate of restenosis that occurs in patients treated with BMS. The superiority of DES has been largely demonstrated, ${ }^{[25]}$ although mortality benefit was only clearly outlined with the later generation of DES. ${ }^{[8]}$ BVS were conceived to avoid long-term complications of the metal structures by providing temporary structural integrity before being resorbed completely within the vessel wall. ${ }^{[9,26]}$ The long-term incidence of cardiovascular events related to DES-treated vessels is around $2 \%$ to $3 \%$ per year for at least 5 years ${ }^{[27,28]}$ and the contribution of permanent metallic devices in lumen target lesions has a relevant contribution. ${ }^{[29]}$ The Absorb $^{\circledR}$ BVS is a $150 \mu \mathrm{m}$ thick bioresorbable polyl-lactide scaffold with a conformal bioresorbable coating (with a total thickness of $7 \mu \mathrm{m}$ ) that elutes everolimus. ${ }^{[30]}$ Angiographic follow-up of BVS has 
Table 4: Results of the multivariate analysis

\begin{tabular}{lcrrrrr}
\hline \multirow{2}{*}{ Characteristics } & \multicolumn{2}{c}{ Cardiovascular mortality } & \multicolumn{2}{c}{ All-cause mortality } & \multicolumn{2}{c}{ Cumulative major cardiovascular events } \\
\cline { 2 - 7 } & $\mathbf{H R}, \mathbf{9 5} \% \mathbf{C l}$ & \multicolumn{1}{c}{$\boldsymbol{P}$} & $\mathbf{H R}, \mathbf{9 5} \% \mathbf{C l}$ & \multicolumn{1}{c}{$\boldsymbol{P}$} & \multicolumn{1}{c}{ IRR, 95\% Cl } & $\boldsymbol{P}$ \\
\hline Age, $>$ 75 years & $3.67(1.82-7.41)$ & $<0.01$ & $3.17(1.75-5.74)$ & $<0.01$ & $1.73(1.26-2.39)$ & $<0.01$ \\
Diabetes & $2.96(1.63-5.36)$ & $<0.01$ & $3.35(2.00-5.62)$ & $<0.01$ & $1.91(1.45-2.53)$ & $<0.01$ \\
Revascularization & $0.69(0.25-1.89)$ & 0.48 & $0.75(0.32-1.77)$ & 0.52 & $0.58(0.33-1.00)$ & 0.05 \\
Previous CVD & $1.01(0.96-1.08)$ & 0.55 & $1.03(0.98-1.08)$ & 0.23 & $1.05(1.01-1.08)$ & $<0.01$ \\
GRACE score $>140$ & $3.27(1.76-6.09)$ & $<0.01$ & $3.49(2.04-5.99)$ & $<0.01$ & $1.12(0.82-1.53)$ & 0.47 \\
\hline
\end{tabular}

HR: hazard ratio; $\mathrm{Cl}$ : confidence intervals; IRR: incidence rate ratio; CVD: cardiovascular disease; GRACE: Global Registry of Acute Coronary Events

clearly demonstrated the complete reabsorption of the scaffolds ${ }^{[9]}$ and significant lumen gain. ${ }^{[31]}$ The initial experience of BVS in our institution supports the clinical safety and efficacy of BVS in ACS patients with a significant post-discharge follow-up.

As with every innovation, concerns arose when data from randomised clinical trials and large numbers of patients treated with BVS became available. The pooled analysis of first studies showed the equivalence at 1-year of BVS compared with everolimus-DES although a non-significant trend (HR: $2.09,95 \% \mathrm{Cl}: 0.92$ to 4.75 , $P=0.08)$ to higher late stent-thrombosis was already outlined. ${ }^{[30]}$ In the ABSORB-II trial, BVS had similar rates of repeat revascularisation at 1 year of follow-up, despite inferior mid-term angiographic performance, in comparison with everolimus-eluting metallic stents. ${ }^{[11]}$ Nonetheless, patients treated with a BVS had a threefold increased risk of subacute stent thrombosis. These results have been verified in subsequent meta-analyses. ${ }^{[12,13]}$ Stent thrombosis is a challenging clinical problem and related to many factors, including the different antiplatelet regimens, discontinuation of dual antiplatelet therapy, procoagulant states, stent malposition, polymer content, and many others. ${ }^{[32,33]}$ Major cardiovascular events and mortality rates in the BVS-treated patients in our cohort were similar or even lower than in patients treated with other stents. Moreover, patients treated with BVS in our study had a higher number of vessels with significant lesions, and subsequently received more stents. This suggests that in well-selected ACS patients under intensive platelet treatment, the use of BVS can be a reasonable strategy of percutaneous revascularisation as has been proposed by other reports ${ }^{[14,15]}$ and meta-analyses..$^{[12,13]}$

BVS-treated patients in our cohort received dual antiplatelet therapy with clopidogrel or the newer antiplatelet drugs, prasugrel or ticagrelor, more frequently than the rest of patients. This could be influenced by many factors, such as the percutaneous coronary intervention characteristics, the number of stents, the younger age or absence of concomitant anticoagulation, but reflects that patients that received a BVS were treated more intensively. The effect of BVS for late adverse events could be especially important for young patients with ACS because they have an impaired vascular healing ${ }^{[34]}$ and new antiplatelet agents could have similar effects. ${ }^{[35]}$ The efficacy of BVS has been tested in only two randomised clinical trials ${ }^{[36,37]}$ and most reports come from observational studies. ${ }^{[14,15,38]}$ The primary endpoint in many of these studies was not cardiovascular mortality, and only the feasibility of the BVS implantation was assessed. We conducted an observational prospective study with the aim of providing mortality rates in a real-world cohort of patients. Moreover, we examined the cumulative incidence of recurrent events, which has been proposed as the best approach to monitor the actual course and prognosis of coronary heart disease. ${ }^{[24]}$

Coronary heart disease is a chronic inflammatory disease and it develops as a result of a progressive process. ${ }^{[39]}$ Despite optimal medical treatment and revascularisation, recurrent events are common. ${ }^{[21,40]}$ The most frequent statistical analyses for follow-up events are based in time-to-events, and therefore, patients are excluded from further analysis once they experience such events. Nonetheless, analysis of recurrent events has been proposed as a more accurate way to assess the actual life-long course and prognosis. ${ }^{[41]}$ Optimal medical treatment has been demonstrated to provide benefit in patients with stable ${ }^{[42]}$ and unstable ${ }^{[21]}$ coronary heart disease regardless of revascularisation. Nonetheless, revascularisation has a much more critical role in ACS patients, and it has been identified as one of the major factors related to long-term ACS survival. Our analysis identified a negative association between revascularisation and recurrent events that provides additional support to its key role in the treatment of ACS patients. STEMI represents less than $40 \%$ of ACS and its emergent treatment requires many resources because acute phase mortality is much higher than in non-STEMI. ${ }^{[1]}$ Nonetheless, the long-term mortality and medical costs are equivalent for both types of ACS. Non-STEMI patients comprise a heterogeneous group, and these patients are usually older and have more comorbidities. This can yield challenging decision-making with regard to revascularisation and medical treatment. As a result, 
revascularisation rates are significantly lower in nonSTEMI compared to STEMI patients, highlighting the unmet needs for validated and organised systems of care for non-STEMI patients. ${ }^{[43]}$ Our results highlight the role of revascularisation for ACS and the recurrence of ischemic events. Stent type was not associated with any of these events although our follow-up suggested that revascularisation has higher impact than the other techniques used.

Our study has several limitations. The first is that a very limited number of patients were treated with BVS. Second, there may have been unmeasured confounders, details about the physician's decisionmaking, or patient factors that are not captured by the registry but account for the treatment differences observed. Furthermore, our analysis uses observational, non-randomised data, and thus, associations between various treatments and outcomes may be confounded by unmeasured variables. Finally, long-term outcomes could be modified by factors that were not captured by the follow-up protocol that was employed at our outpatient centres. Nonetheless, since clinical features and event rates are similar to previous reports, ${ }^{[4,36-38]}$ we believe that our results should be representative of daily clinical practice and that our conclusions are probably valid.

In conclusion, our study supports the hypothesis that coronary revascularisation using BVS is safe and effective in selected ACS patients. Percutaneous coronary revascularisation with stents is the cornerstone of ACS treatment but there are long-term complications of metallic devices that can be relevant. The use of BVS is a novel strategy with promising results, and there is an expectation that they will prove useful in ACS selected patients. The long term prognosis of BVS-treated patients remains unknown, but given the growing number of patients being treated with these devices, further evidence regarding their net clinical benefit will likely emerge with additional time.

\section{Authors' contributions}

Manuscript's conception and writting: A. Cordero, R. López-Palop and P. Carrillo

Data base fulfilment: A. Cordero, C. Gunturiz, M. Garcia-Carrilero

Manuscript's revision: A. Frutos, V. Bertomeu-Martinez

\section{Financial support and sponsorship}

None.

\section{Conflicts of interest}

There are no conflicts of interest.

\section{Patient consent}

All patients included in the registry provided the informed consent.

\section{Ethics approval}

The ethics committee of the hospital approved the study protocol and informed consent.

\section{REFERENCES}

1. Mozaffarian D, Benjamin EJ, Go AS, Arnett DK, Blaha MJ, Cushman M, Das SR, de Ferranti S, Despres JP, Fullerton HJ, Howard VJ, Huffman MD, Isasi CR, Jimenez MC, Judd SE, Kissela BM, Lichtman JH, Lisabeth LD, Liu S, Mackey RH, Magid DJ, McGuire DK, Mohler ER 3rd, Moy CS, Muntner P, Mussolino ME, Nasir K, Neumar RW, Nichol G, Palaniappan L, Pandey DK, Reeves MJ, Rodriguez CJ, Rosamond W, Sorlie PD, Stein J, Towfighi A, Turan TN, Virani SS, Woo D, Yeh RW, Turner MB; American Heart Association Statistics Committee; Stroke Statistics Subcommittee. Heart Disease and Stroke Statistics-2016 Update: a report from the American Heart Association. Circulation 2016;133:e38-360.

2. Crea F, Liuzzo G. Pathogenesis of acute coronary syndromes. $J$ Am Coll Cardiol 2013;61:1-11.

3. Roffi M, Patrono C, Collet JP, Mueller C, Valgimigli M, Andreotti F, Bax JJ, Borger MA, Brotons C, Chew DP, Gencer B, Hasenfuss G, Kjeldsen K, Lancellotti P, Landmesser U, Mehilli J, Mukherjee D, Storey RF, Windecker S, Baumgartner H, Gaemperli O, Achenbach S, Agewall S, Badimon L, Baigent C, Bueno H, Bugiardini R, Carerj S, Casselman F, Cuisset T, Erol C, Fitzsimons D, Halle M, Hamm C, Hildick-Smith D, Huber K, Iliodromitis E, James S, Lewis BS, Lip GY, Piepoli MF, Richter D, Rosemann T, Sechtem U, Steg PG, Vrints C, Luis Zamorano J; Management of Acute Coronary Syndromes in Patients Presenting without Persistent ST-Segment Elevation of the European Society of Cardiology. 2015 ESC Guidelines for the management of acute coronary syndromes in patients presenting without persistent ST-segment elevation: Task Force for the Management of Acute Coronary Syndromes in Patients Presenting without Persistent ST-Segment Elevation of the European Society of Cardiology (ESC). Eur Heart J 2016;37:267-315.

4. Barrabes JA, Bardaji A, Jimenez-Candil J, del Nogal Saez F, Bodi V, Basterra N, Marco E, Melgares R, Cunat de la Hoz J, Fernandez-Ortiz $\mathrm{A}$; investigators of DIOCLES study. Prognosis and management of acute coronary syndrome in Spain in 2012: the DIOCLES study. Rev Esp Cardiol 2015;68:98-106.

5. Cordero A, Lopez-Palop R, Carrillo P, Frutos A, Miralles S, Gunturiz C, Garcia-Carrilero M, Bertomeu-Martinez V. Changes in acute coronary syndrome treatment and prognosis after implementation of the infarction code in a hospital with a cardiac catheterization unit. Rev Esp Cardiol (Engl Ed) 2016;69:754-9.

6. Serruys PW, Garcia-Garcia HM, Onuma Y. From metallic cages to transient bioresorbable scaffolds: change in paradigm of coronary revascularization in the upcoming decade? Eur Heart J 2012;33:16$25 \mathrm{~b}$.

7. Ko DT, Tu JV, Samadashvili Z, Guo H, Alter DA, Cantor WJ, Hannan EL. Temporal trends in the use of percutaneous coronary intervention and coronary artery bypass surgery in New York State and Ontario. Circulation 2010;121:2635-44.

8. Windecker S, Stortecky S, Stefanini GG, da Costa BR, Rutjes AW, Di Nisio M, Silletta MG, Maione A, Alfonso F, Clemmensen PM, Collet JP, Cremer J, Falk V, Filippatos G, Hamm C, Head S, Kappetein AP, Kastrati A, Knuuti J, Landmesser U, Laufer G, Neumann FJ, Richter D, Schauerte P, Sousa Uva M, Taggart DP, Torracca L, Valgimigli 
M, Wijns W, Witkowski A, Kolh P, Jüni P. Revascularisation versus medical treatment in patients with stable coronary artery disease: network meta-analysis. BMJ 2014;348:g3859.

9. Onuma Y, Serruys PW, Perkins LE, Okamura T, Gonzalo N, GarciaGarcia HM, Regar E, Kamberi M, Powers JC, Rapoza R, van Beusekom H, van der Giessen W, Virmani R. Intracoronary optical coherence tomography and histology at 1 month and 2, 3, and 4 years after implantation of everolimus-eluting bioresorbable vascular scaffolds in a porcine coronary artery model: an attempt to decipher the human optical coherence tomography images in the ABSORB trial. Circulation 2010;122:2288-300.

10. Tamai H, Igaki K, Kyo E, Kosuga K, Kawashima A, Matsui S, Komori H, Tsuji T, Motohara S, Uehata H. Initial and 6-month results of biodegradable poly-1-lactic acid coronary stents in humans. Circulation 2000;102:399-404.

11. Serruys PW, Chevalier B, Sotomi Y, Cequier A, Carrie D, Piek JJ, Van Boven AJ, Dominici M, Dudek D, McClean D, Helqvist S, Haude M, Reith S, de Sousa Almeida M, Campo G, Iniguez A, Sabate $\mathrm{M}$, Windecker S, Onuma Y. Comparison of an everolimus-eluting bioresorbable scaffold with an everolimus-eluting metallic stent for the treatment of coronary artery stenosis (ABSORB II): a 3 year, randomised, controlled, single-blind, multicentre clinical trial. Lancet 2016;388:2479-91.

12. Cassese S, Byrne RA, Ndrepepa G, Kufner S, Wiebe J, Repp J, Schunkert H, Fusaro M, Kimura T, Kastrati A. Everolimus-eluting bioresorbable vascular scaffolds versus everolimus-eluting metallic stents: a meta-analysis of randomised controlled trials. Lancet 2016;387:537-44.

13. Lu C, Filion KB, Eisenberg MJ. The safety and efficacy of Absorb bioresorbable vascular scaffold: a systematic review. Clin Cardiol 2016;39:48-55.

14. Gori T, Schulz E, Hink U, Wenzel P, Post F, Jabs A, Münzel T. Early outcome after implantation of Absorb bioresorbable drug-eluting scaffolds in patients with acute coronary syndromes. EuroIntervention 2014;9:1036-41.

15. Kočka V, Malý $M$, Toušek $P$, Buděšínský $T$, Lisa L, Prodanov P, Jarkovský J, Widimský P. Bioresorbable vascular scaffolds in acute ST-segment elevation myocardial infarction: a prospective multicentre study 'Prague 19'. Eur Heart J 2014;35:787-94.

16. Cordero A, Moreno-Arribas J, Bertomeu-González V, Agudo P, Miralles B, Masiá MD, López-Palop R, Bertomeu-Martinez V. Low levels of high-density lipoproteins cholesterol are independently associated with acute coronary heart disease in patients hospitalized for chest pain. Rev Esp Cardiol 2012;65:319-25.

17. Farooq V, Serruys PW, Garcia-Garcia HM, Zhang Y, Bourantas CV, Holmes DR, Mack M, Feldman T, Morice MC, Stahle E, James S, Colombo A, Diletti R, Papafaklis MI, de Vries T, Morel MA, van Es GA, Mohr FW, Dawkins KD, Kappetein AP, Sianos G, Boersma E. The negative impact of incomplete angiographic revascularization on clinical outcomes and its association with total occlusions: the SYNTAX (Synergy Between Percutaneous Coronary Intervention with Taxus and Cardiac Surgery) trial. J Am Coll Cardiol 2013;61:282-94.

18. Garcia S, Sandoval Y, Roukoz H, Adabag S, Canoniero M, Yannopoulos D, Brilakis ES. Outcomes after complete versus incomplete revascularization of patients with multivessel coronary artery disease: a meta-analysis of 89,883 patients enrolled in randomized clinical trials and observational studies. $\mathrm{J} \mathrm{Am} \mathrm{Coll}$ Cardiol 2013;62:1421-31.

19. Sachdev M, Sun JL, Tsiatis AA, Nelson CL, Mark DB, Jollis JG. The prognostic importance of comorbidity for mortality in patients with stable coronary artery disease. J Am Coll Cardiol 2004;43:576-82.

20. Boden WE, O’Rourke RA, Teo KK, Hartigan PM, Maron DJ, Kostuk WJ, Knudtson M, Dada M, Casperson P, Harris CL, Chaitman BR,
Shaw L, Gosselin G, Nawaz S, Title LM, Gau G, Blaustein AS, Booth DC, Bates ER, Spertus JA, Berman DS, Mancini GB, Weintraub WS; COURAGE Trial Research Group. Optimal medical therapy with or without PCI for stable coronary disease. NEngl J Med 2007;356:150316.

21. Iqbal J, Zhang YJ, Holmes DR, Morice MC, Mack MJ, Kappetein AP, Feldman T, Stahle E, Escaned J, Banning AP, Gunn JP, Colombo A, Steyerberg EW, Mohr FW, Serruys PW. Optimal medical therapy improves clinical outcomes in patients undergoing revascularization with percutaneous coronary intervention or coronary artery bypass grafting: insights from the synergy between percutaneous coronary intervention with TAXUS and cardiac surgery (SYNTAX) trial at the 5-year follow-up. Circulation 2015;131:1269-77.

22. Stone NJ, Robinson JG, Lichtenstein AH, Bairey Merz CN, Blum CB, Eckel RH, Goldberg AC, Gordon D, Levy D, Lloyd-Jones DM, McBride P, Schwartz JS, Shero ST, Smith SC Jr, Watson K, Wilson PW; American College of Cardiology/American Heart Association Task Force on Practice Guidelines. 2013 ACC/AHA Guideline on the treatment of blood cholesterol to reduce atherosclerotic cardiovascular risk in adults: a report of the American College of Cardiology/ American Heart Association Task Force on Practice Guidelines. J Am Coll Cardiol 2014;63:2889-934.

23. Catapano AL, Graham I, De Backer G, Wiklund O, Chapman MJ Drexel H, Hoes AW, Jennings CS, Landmesser U, Pedersen TR, Reiner Ž, Riccardi G, Taskinen MR, Tokgozoglu L, Verschuren WM, Vlachopoulos C, Wood DA, Zamorano JL. 2016 ESC/EAS Guidelines for the management of dyslipidaemias: the Task Force for the Management of Dyslipidaemias of the European Society of Cardiology (ESC) and European Atherosclerosis Society (EAS) developed with the special contribution of the European Assocciation for Cardiovascular Prevention \& Rehabilitation (EACPR). Atherosclerosis 2016;253:281-344.

24. Rogers JK, Pocock SJ, McMurray JJ, Granger CB, Michelson EL, Ostergren J, Pfeffer MA, Solomon SD, Swedberg K, Yusuf S. Analysing recurrent hospitalizations in heart failure: a review of statistical methodology, with application to CHARM-Preserved. Eur $J$ Heart Fail 2014;16:33-40.

25. Windecker S, Kolh P, Alfonso F, Collet JP, Cremer J, Falk V, Filippatos G, Hamm C, Head SJ, Jüni P, Kappetein AP, Kastrati A, Knuuti J, Landmesser U, Laufer G, Neumann FJ, Richter DJ, Schauerte P, Sousa Uva M, Stefanini GG, Taggart DP, Torracca L, Valgimigli M, Wijns W, Witkowski A. 2014 ESC/EACTS Guidelines on myocardial revascularization: the Task Force on Myocardial Revascularization of the European Society of Cardiology (ESC) and the European Association for Cardio-Thoracic Surgery (EACTS) developed with the special contribution of the European Association of Percutaneous Cardiovascular Interventions (EAPCI). Eur Heart J 2014;35:2541-619.

26. Karanasos A, Simsek C, Gnanadesigan M, van Ditzhuijzen NS, Freire R, Dijkstra J, Tu S, Van Mieghem N, van Soest G, de Jaegere P, Serruys PW, Zijlstra F, van Geuns RJ, Regar E. OCT assessment of the long-term vascular healing response 5 years after everolimus-eluting bioresorbable vascular scaffold. J Am Coll Cardiol 2014;64:2343-56.

27. Stone GW, Maehara A, Lansky AJ, de Bruyne B, Cristea E, Mintz GS, Mehran R, McPherson J, Farhat N, Marso SP, Parise H, Templin B, White R, Zhang Z, Serruys PW; PROSPECT Investigators. A prospective natural-history study of coronary atherosclerosis. $N \mathrm{Engl}$ J Med 2011;364:226-35.

28. Taniwaki M, Stefanini GG, Silber S, Richardt G, Vranckx P, Serruys PW, Buszman PE, Kelbaek H, Windecker S; RESOLUTE All-Comers Investigators. 4-year clinical outcomes and predictors of repeat revascularization in patients treated with new-generation drug-eluting stents: a report from the RESOLUTE All-Comers trial 
(A Randomized Comparison of a Zotarolimus-Eluting Stent With an Everolimus-Eluting Stent for Percutaneous Coronary Intervention). $J$ Am Coll Cardiol 2014;63:1617-25.

29. Tada T, Kadota K, Hosogi S, Miyake K, Ohya M, Amano H, Izawa Y, Kanazawa T, Kubo S, Ichinohe T, Hyoudou Y, Hayakawa Y, Sabbah MM, Otsuru S, Hasegawa D, Habara S, Tanaka H, Fuku Y, Katoh $\mathrm{H}$, Goto T, Mitsudo K. Association between tissue characteristics assessed with optical coherence tomography and mid-term results after percutaneous coronary intervention for in-stent restenosis lesions: a comparison between balloon angioplasty, paclitaxel-coated balloon dilatation, and drug-eluting stent implantation. Eur Heart $J$ Cardiovasc Imaging 2015;16:1101-11.

30. Stone GW, Gao R, Kimura T, Kereiakes DJ, Ellis SG, Onuma Y, Cheong WF, Jones-McMeans J, Su X, Zhang Z, Serruys PW. 1-year outcomes with the Absorb bioresorbable scaffold in patients with coronary artery disease: a patient-level, pooled meta-analysis. Lancet 2016;387:1277-89.

31. Lane JP, Perkins LE, Sheehy AJ, Pacheco EJ, Frie MP, Lambert BJ, Rapoza RJ, Virmani R. Lumen gain and restoration of pulsatility after implantation of a bioresorbable vascular scaffold in porcine coronary arteries. JACC Cardiovasc Interv 2014;7:688-95.

32. de la Torre-Hernández JM, Alfonso F, Hernández F, Elizaga J, Sanmartin M, Pinar E, Lozano I, Vazquez JM, Botas J, Perez de PA, Hernández JM, Sanchis J, Nodar JM, Gomez-Jaume A, Larman M, Diarte JA, Rodríguez-Collado J, Rumoroso JR, Lopez-Minguez JR, Mauri J; ESTROFA Study Group. Drug-eluting stent thrombosis: results from the multicenter Spanish registry ESTROFA (Estudio ESpanol sobre TROmbosis de stents FArmacoactivos). J Am Coll Cardiol 2008;51:986-90.

33. Baber U, Mehran R, Giustino G, Cohen DJ, Henry TD, Sartori S, Ariti C, Litherland C, Dangas G, Gibson CM, Krucoff MW, Moliterno DJ, Kirtane AJ, Stone GW, Colombo A, Chieffo A, Kini AS, Witzenbichler B, Weisz G, Steg PG, Pocock S. Coronary thrombosis and major bleeding after PCI with drug-eluting stents: risk scores from PARIS. J Am Coll Cardiol 2016;67:2224-34

34. Nakazawa G, Finn AV, Joner M, Ladich E, Kutys R, Mont EK, Gold HK, Burke AP, Kolodgie FD, Virmani R. Delayed arterial healing and increased late stent thrombosis at culprit sites after drug-eluting stent placement for acute myocardial infarction patients: an autopsy study. Circulation 2008;118:1138-45.

35. Vilahur G, Gutierrez M, Casani L, Varela L, Capdevila A, PonsLlado G, Carreras F, Carlsson L, Hidalgo A, Badimon L. Protective effects of ticagrelor on myocardial injury after infarction. Circulation
2016;134:1708-19.

36. Brugaletta S, Gori T, Low AF, Tousek P, Pinar E, Gomez-Lara J, Scalone G, Schulz E, Chan MY, Kocka V, Hurtado J, GomezHospital JA, Münzel T, Lee CH, Cequier A, Valdés M, Widimsky P, Serruys PW, Sabaté M. Absorb bioresorbable vascular scaffold versus everolimus-eluting metallic stent in ST-segment elevation myocardial infarction: 1-year results of a propensity score matching comparison: the BVS-EXAMINATION Study (bioresorbable vascular scaffold-a clinical evaluation of everolimus eluting coronary stents in the treatment of patients with ST-segment elevation myocardial infarction). JACC Cardiovasc Interv 2015;8:189-97.

37. Sabaté M, Windecker S, Iñiguez A, Okkels-Jensen L, Cequier A Brugaletta S, Hofma SH, Räber L, Christiansen EH, Suttorp M, Pilgrim T, Anne van Es G, Sotomi Y, García-García HM, Onuma Y, Serruys PW. Everolimus-eluting bioresorbable stent vs. durable polymer everolimus-eluting metallic stent in patients with STsegment elevation myocardial infarction: results of the randomized ABSORB ST-segment elevation myocardial infarction-TROFI II trial. Eur Heart J 2016;37:229-40.

38. Capodanno D, Gori T, NefH, Latib A, Mehilli J, Lesiak M, Caramanno G, Naber C, Di Mario C, Colombo A, Capranzano P, Wiebe J, Araszkiewicz A, Geraci S, Pyxaras S, Mattesini A, Naganuma T, Münzel T, Tamburino C. Percutaneous coronary intervention with everolimus-eluting bioresorbable vascular scaffolds in routine clinical practice: early and midterm outcomes from the European multicentre GHOST-EU registry. EuroIntervention 2015;10:1144-53.

39. Libby P. Inflammation in atherosclerosis. Nature 2002;420:868-74

40. Andrés E, Cordero A, Magán P, Alegría E, León M, Luengo E, Botaya RM, García Ortiz L, Casasnovas JA. Long-term mortality and hospital readmission after acute myocardial infarction: an eight-year follow-up study. Rev Esp Cardiol 2012;65:414-20.

41. Rogers JK, Yaroshinsky A, Pocock SJ, Stokar D, Pogoda J. Analysis of recurrent events with an associated informative dropout time: application of the joint frailty model. Stat Med 2016;35:2195-205.

42. Sedlis SP, Hartigan PM, Teo KK, Maron DJ, Spertus JA, Mancini GB, Kostuk W, Chaitman BR, Berman D, Lorin JD, Dada M, Weintraub WS, Boden WE; COURAGE Trial Investigators. Effect of PCI on long-term survival in patients with stable ischemic heart disease. $N$ Engl J Med 2015;373:1937-46.

43. Cordero A, Carrillo P, López-Palop R. Letter by Cordero et al regarding article, "Regional systems of care demonstration project: American Heart Association Mission: Lifeline STEMI Systems Accelerator". Circulation 2016;134:e700-1. 